\title{
Reduced Levels of Arsenic in Drinking Water Using Ferric Oxide Hydroxy
}

\author{
Graieb J. O. ${ }^{1, *}$, Lujan J. C. ${ }^{1}$, Graieb C. V. ${ }^{1}$, Llanos R. ${ }^{1}$, Bautista J. C. ${ }^{1}$, Mangini G. ${ }^{2}$, Viscido C. A. ${ }^{2}$, \\ Ojeda G. ${ }^{2}$, Ferrari R. R. ${ }^{2}$, Valla $S^{3}$ \\ ${ }^{1}$ Environmental Engineering Research Center, Faculty of Regional Tucuman, National Technological University, Argentina \\ ${ }^{2}$ Department of Chemistry, Faculty of Regional Tucuman, National Technological University, Argentina \\ ${ }^{3}$ Department of Information Systems Engineering, Faculty of Regional Tucuman, National Technological University, Argentina
}

Copyright $\bigcirc 2016$ by authors, all rights reserved. Authors agree that this article remains permanently open access under the terms of the Creative Commons Attribution License 4.0 International License

\begin{abstract}
This paper aims to test the efficiency of arsenic removal in drinking water, using oxide hydroxide granulated iron in with a pilot a portable plant in three different sources in the towns of Romera Pozo and Agua Azul Province Tucuman, with varied content of initial arsenic. A large treatment capacity, for certain types of water wherein the $\mathrm{pH}$ and silica content are key determinants of the matrices of treated water was observed. The results of the studies conducted in the three sources of arsenical waters with $\mathrm{pH}$ between 8 to 8.6 , and silica between 59 to $60.5[\mathrm{mg} / \mathrm{L}]$ show the treated water reaching the limit of $10[\mu \mathrm{g} / \mathrm{L}]$ arsenic the following: for water with $65[\mu \mathrm{g} / \mathrm{L}]$ arsenic the treated volume was 20,000 bed volumes, 16,000 to $110[\mu \mathrm{g} / \mathrm{L}]$ and 2.000 to $920[\mu \mathrm{g} / \mathrm{L}]$.
\end{abstract}

Keywords Hydroarsenicism, Cerha, Hacre, Arsenicosis, Water Quality, Arsenic, Water

\section{Introduction}

The risk Cronic Endemic Regional Hydroarsenicism (HACRE in its Spanish initials) or (CERHA) also Arsenicosis, is mainly due to the consumption of drinking water from perforated wells of shallow aquifers in the eastern part of the Province of Tucuman [1] (M. Garcia , 2006), [2] (Graieb O., 2006).

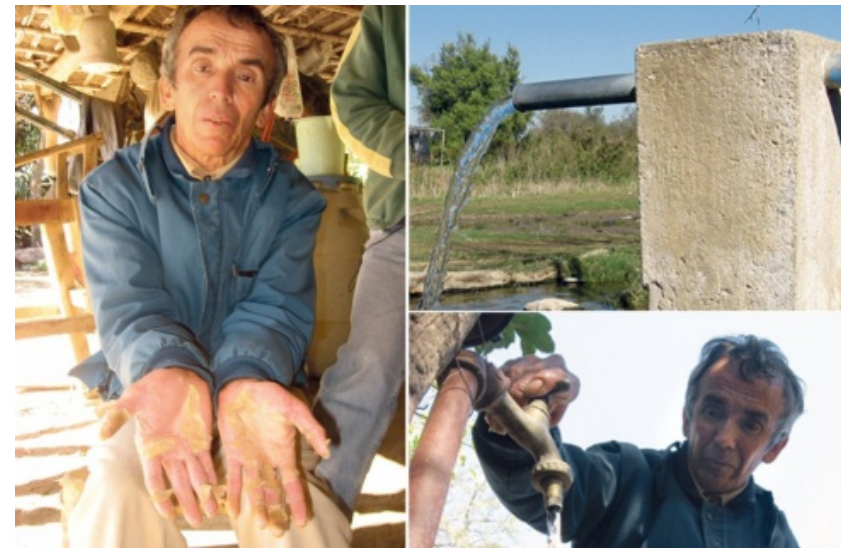

Figure 1. "With skin lacerated by arsenic water" La Gaceta Daily, Tucuman -27/06/11

The depth of these wells varies between 2 meters to 20 meters. The drinking water wells first cursory layer has high content of As (V) and As (III), prevailing As (V). In the area of Ranchillos and zones of influence, the values vary between 20 and $700[\mu \mathrm{g} / \mathrm{L}]$, with an average of $279[\mu \mathrm{g} / \mathrm{L}]$ [1] (M. Garcia, 2006). The $\mathrm{pH}$ varies between 6.8 and 8.6 with an average of 7.8. According to [3] (Viapiano, 1996), most wells water supply in the De-departments in Cruz Alta, Loyalists and Granary above 10 [ $\mu \mathrm{g} / \mathrm{L}]$, with peak values from 1000 to 1200 [ $\mu \mathrm{g} / \mathrm{L}$ ] of arsenic. [4] (Fernandez \& Graieb 2006) found average values of $500[\mu \mathrm{g} / \mathrm{L}]$ for the same region. 
The presence of arsenic in concentrations exceeding the limits set by the Argentine Food Code [5] (C.A.A., 2013) in drinking water affects the population used to drink water from wells of the first level aquifer throughout the rural area east and some deep waters to the south west of the Province of Tucuman [6] (Nicoli et al., 2007).

Water samples analyzed in this work exceeds the allowed values. Arsenical samples were analyzed (a) $<100[\mu \mathrm{g} / \mathrm{L}]$; (b) $100[\mu \mathrm{g} / \mathrm{L}]-150[\mu \mathrm{g} / \mathrm{L}]$; (c) $900[\mu \mathrm{g} / \mathrm{L}]-1000[\mu \mathrm{g} / \mathrm{L}]$. The analysis method was utlizado by colorimetry with diethyl dithiocarbamate silver [7] (Standard Methods., 2002).

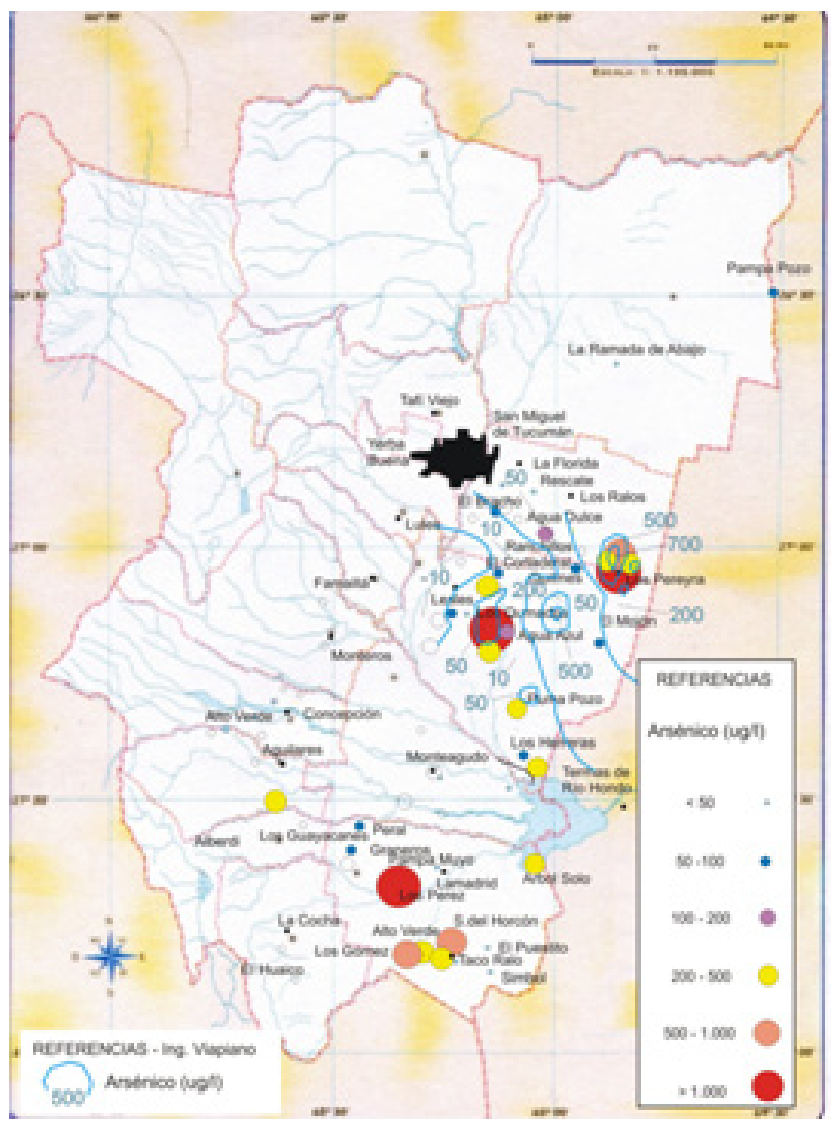

Figure 2. Distribution of arsenic in groundwater water table in the Province of Tucuman [8] (Graieb O. J. et al., 2008).

Figure 2 shows the distribution of arsenic in groundwater noted in aquifers in the Province of Tucuman [8] (Graieb O. J. et al., 2008).

\section{Objective}

This paper aims to validate selectively removing arsenic in drinking water using Granular Ferric Oxide-Hydroxide in preliminary laboratory tests and field ex-perience.

\section{Methods / Experimental}

\subsection{Choosing a Method for Treatment}

Studies indicate that only As (V) can be eliminated from water effectively. If the As (III) is present in natural water sources, oxidation thereof is essential in dejection methods [9] (Lujan, 2001). Arsenic removal with ferric salts, followed by coagulation and filtration are known techniques that allow relatively low dose of ferric salts with very low final concentrations of arsenic. Osmosis and nanofiltration can be satisfactory for treatment, but with high rejection of salt water and high cost for users. The Arsenic adsorption with activated alumina is a simple and effective method to reduce the arsenic content [9] (Lujan, 2001), [2] (Graieb O. J. et al. 2006). In the process of coagulation-filtration ferric salts show better removal efficiency than the same dose of alumina [10] (Pierce M. L. Moore and C. B., 1982). Therefore the use of a granular activated ferric oxide or ferric hydroxide should show a large capacity for the adsorption of arsenic from water using a fixed bed.

\subsection{Granular Iron Hydroxide}

According to [11] (Pal, 2011) granulated iron hydroxide has high porosity and a surface area of approx. $75 \%$ and up to $300 \mathrm{~m}^{2} /$ gram, respectively. Arsenic (III and V) is adsorbed on a wide $\mathrm{pH}$ range (7 to 8.5), taking competition with phosphate influencing the contents of iron, manganese and silica. The residual product of the treatment process is a small quantity compact granule that can be handled with secured disposal in authorized hazardous waste companies.

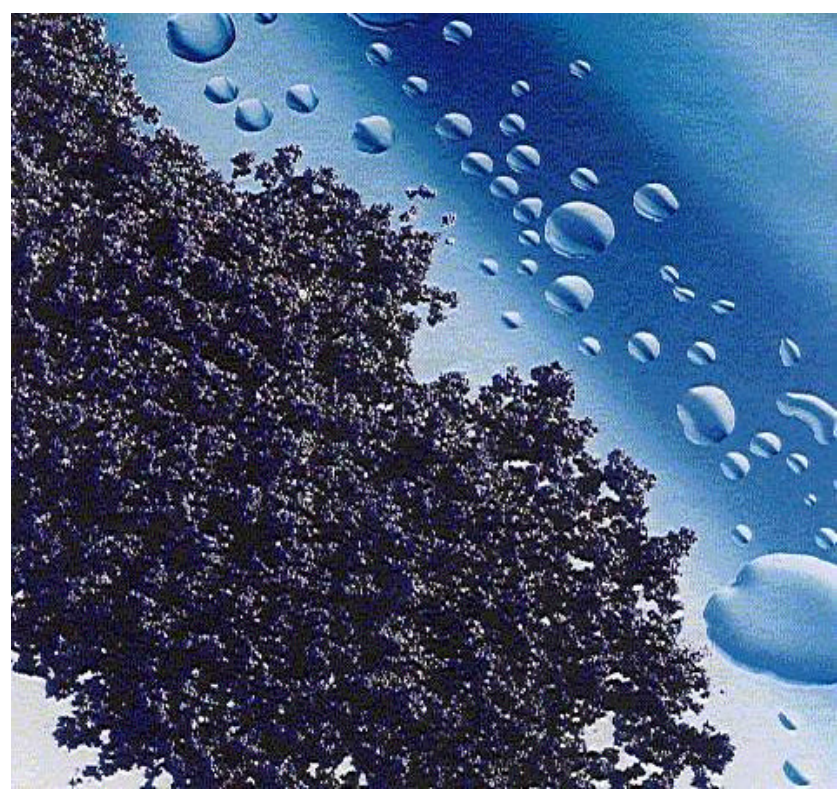

Figure 3. Granular ferric hydroxide Developed at the Technical University of Berlin, Germany, Department of Water Quality Control

Made from a solution of ferric chloride and precipitation by neutralization with sodium hydroxide. As there is a drying process in preparation, all pores are filled completely with water, resulting in a high density of adsorption sites available 
and therefore a high adsorption capacity. Studies on the adsorption of both forms of arsenic amorphous ferric hydroxide had determined that such material should have 5 to 10 times more efficiently than Activated Alumina. Also in the process of coagulation-filtration ferric salts show better removal efficiency of alum in equal doses. Therefore, it is expected that a granular activated ferric oxide or ferric hydroxide must have a greater capacity for adsorption of arsenic from water activated alumina in a fixed bed system.

Porosity: Reference porosity [11] (Pal B. N., 2011).

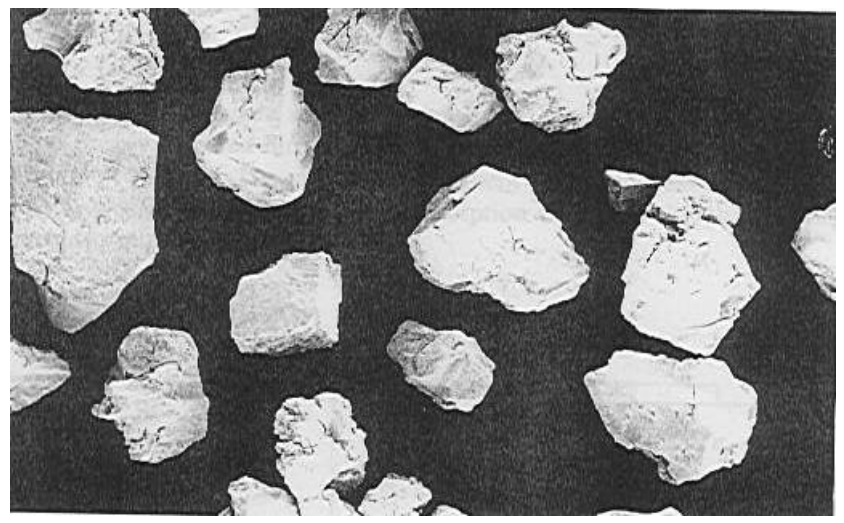

Figure 4. synthetic iron hydroxide manufactured with a porosity of about $75 \%$ and the specific surface area $250-300 \mathrm{~m} 2 / \mathrm{g}$.

\subsection{Design of Laboratory and Field Equipment}

It is designed and set a laboratory tank with 20 liters and two filters in series, one of hi-iron hydroxide granulate and other activated carbon (for adjusting the taste of some water). The samples were collected from some addresses of the various departments of the Province of Tucuman mentioned above. Fixed beds (HHG) is initially constructed with 500 gr. Granulated iron hydroxide, quantity. The following aspects are considered for optimization of the process:

- That the amounts of arsenic removed comply with the Regulations $[\mu \mathrm{g} / \mathrm{L}]$

- That the final iron content does not affect the taste of water.

- That the speed of passage allows the preparation of 10 to 15 liters of water per day.

- That the equipment can be used so that the costs are affordable for the rural population.

The chemical variables measured before and after the passage of water through the filter were: $\mathrm{pH}$, conductivity, arsenic, iron content, Hardness and Turbidity. The device was built for a family group of 5 people, who consume about 10 to $15 \mathrm{~L}$ of water per day, for drinking and food preparation.

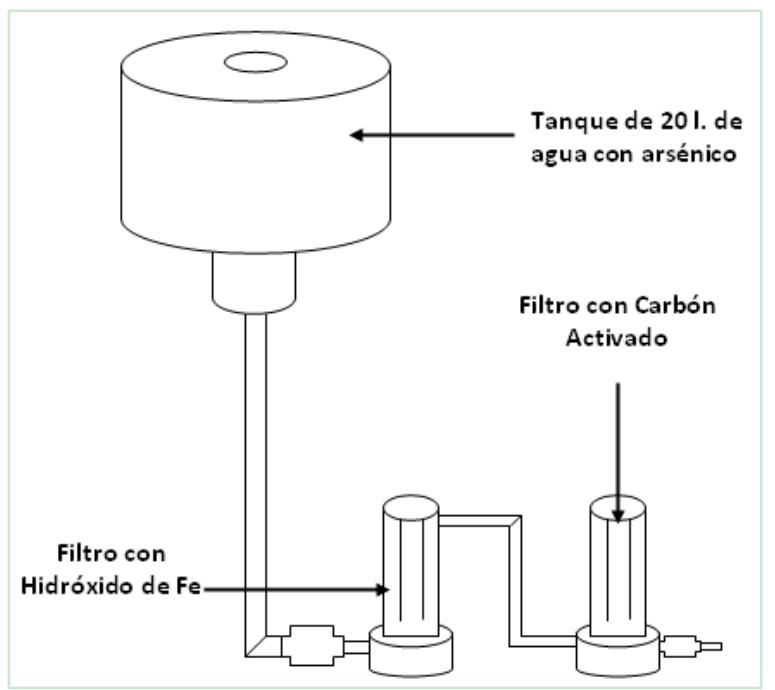

Figure 5. Diagram removal system of and arsenic laboratory field removal

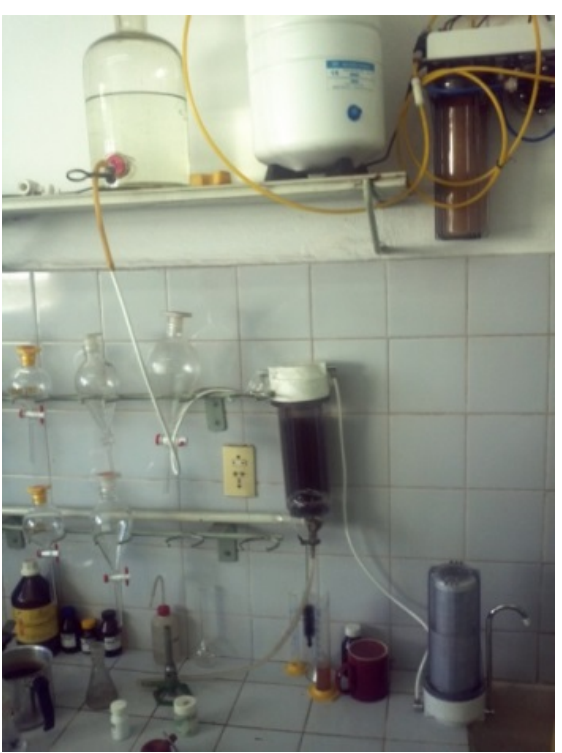

Figure 6. Laboratory Equipment removal Arsenic

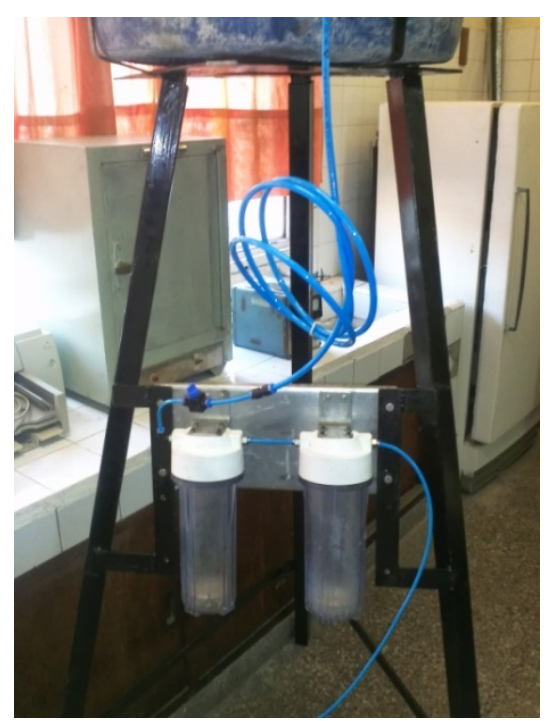

Figure 7. Calibration laboratory equipment 


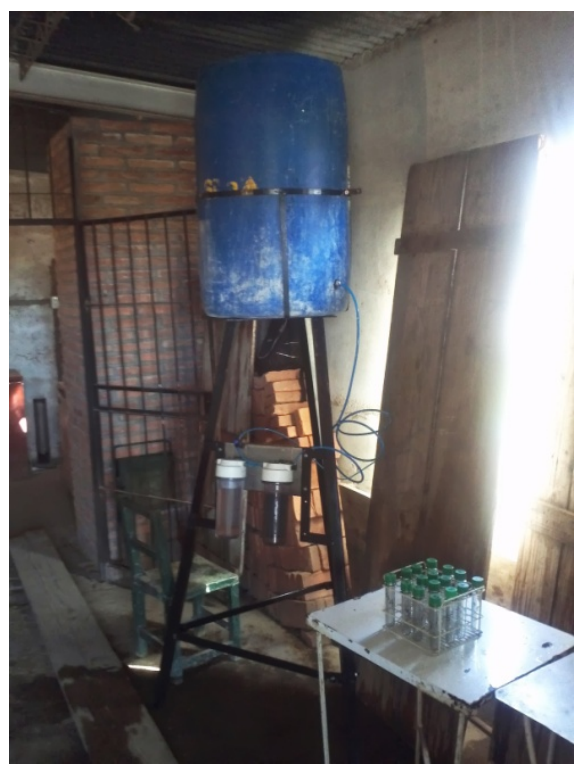

Figure 8. Field team working on a rural housing field

\subsection{Matrix of the Water to Be Treated}

With foreknowledge of the matrix of drinking water from underground sources especially the first aquifer used mainly in scattered dwellings in endemic areas of arsenicosis chronic be possible to use hydroxide granulated iron as technology accessible to their socioeconomic status.

The concentration of arsenic in groundwater before treatment may be accompanied by content of chemical species that can hinder the effectiveness of their elimination, in addition to its $\mathrm{pH}$ level. Phosphates, silica and iron content in water before treatment are this kind of arsenic abatement limiting species. A study of the matrix shows water treatment capacity of the adsorbent. Our experience focused on the removal of arsenic from water with various initial arsenic content of $65[\mu \mathrm{g} / \mathrm{L}], 110[\mu \mathrm{g} / \mathrm{L}], 920[\mu \mathrm{g} / \mathrm{L}]$ and $\mathrm{pH}$ between 8 and 8.6 of locations Romera Pozo and Agua Azul in the province of Tucuman.

\section{Results and Discussion}

The arsenic content was analyzed by colorimetry with diethyl dithiocarbamate silver [7] (Standard Methods. 2002). Each bed was prepared with $465 \mathrm{~cm}^{3}$ of HHG (granulated iron hydroxide). The results indicate that initial iron content of between 130 and $160[\mu \mathrm{g} / \mathrm{L}]$ decreased to less than 20 $[\mu \mathrm{g} / \mathrm{L}]$. The conductivity slightly decreases by $10 \%$. Expressed in carbonate hardness increased slightly by 5 to $7 \%$. In all tests arsenic removal was passed a flow of water through the bed to detect the presence of arsenic content of $10[\mu \mathrm{g} / \mathrm{L}]$. The initial silica content between 59 and 60.5 $[\mathrm{mg} / \mathrm{L}]$ were significantly reduced. Initial although not relevant $(0.25[\mathrm{mg} / \mathrm{L}])$, phosphates were not detected in the outlet water. In the plant operation with initial content of 65 $[\mu \mathrm{g} / \mathrm{L}]$ has exceeded $10[\mu \mathrm{g} / \mathrm{L}]$ in treated water after
$10,000 \mathrm{~L}$. For operation with initial content of $110[\mu \mathrm{g} / \mathrm{L}]$ he was exceeded after $8,000 \mathrm{~L}$ and water with $920[\mu \mathrm{g} / \mathrm{L}]$ 1,000 L. Fixed beds (HHG) used must be disposed of toxic waste plant.

\section{Conclusions}

The results of the studies carried out with natural groundwater using a mobile treatment plant in the towns Romera Pozo Azul and Agua province of Tucuman, show that step volumes depend on the initial concentration of arsenic. Water three sources different initial concentrations of arsenic with $\mathrm{pH}$ between 8 and 8.6 were analyzed until the treated water exceeds the allowed limit saturation point of 10 $[\mu \mathrm{g} / \mathrm{L}]$. They reached this value after the passage 20,000 volumes of water cartridge containing $65[\mu \mathrm{g} / \mathrm{L}]$ arsenic; 16,000 volumes waters with contents of $110[\mu \mathrm{g} / \mathrm{L}]$ arsenic and 2,000 volumes of water containing $920[\mu \mathrm{g} / \mathrm{L}]$ of arsenic. The silica content between 59 and $60.5[\mathrm{mg} / \mathrm{L}]$ is de-strict key to the effectiveness of the removal of arsenic.

The results are comparatively equivalent to those found by [12] (Storniolo et al, 2009) at work on removing arsenic and other elements.

\section{Acknowledgements}

We thank the Community of Romera Pozo and Agua Azul. In the Water Society of Tucuman laboratories (S.A.T), S.I.P.R.O.S.A. and the Center for Environmental Research and Development Engineering (C.E.D.I.A.) UTN - FRT.

\section{REFERENCES}

[1] García, M. et al. 2006. Factors affecting arsenic concentration in groundwaters 4 from Northwestern Chaco-Pampean Plain, Argentina.

[2] Graieb, O.J.; Graieb V.C. y Tintilay S.C. 2006. Tecnología Para El Abordaje Del Hacre En Pobladores Rurales Dispersos.

[3] Viapiano, J.S. 1996. Informe breve sobre Hidroarsenicismo (HACRE). Departamento Básico. Documento SIPROSA. Tucumán.

[4] Fernández, R.I. y Graieb, O.J. 2006. La presencia de arsénico como factor de riesgo geoambiental en la provincia de Tucumán. Argentina - cedia utn-frt.

[5] CAA. Codigo Alimentario Argentino. 2013.

[6] Nicoli; Garcia, W.; Falcon, C. y Tineo, A. 2007. Contaminación com arsenico de fuentes de águas subterraneas en la Cuenca del Rio Salí - Argentina. Water Rock Interaction - Kunming Yunnan (China)

[7] Standard Methods, American Public Health Association (APHA), The American Water Works Association (AWWA) 
and the Water Environment Federation (WEF) 2002

[8] Graieb, Oscar J.; García, Jorge W., Falcón, Carlos M. y Sayago, José M. Contribución de materiales loesicos en el contenido de arsénico en aguas subterráneas de la llanura oriental tucumana - CONAGUA 2008.

[9] Lujan, J.C. 2001. Un hidrogel de hidróxido de aluminio para eliminar el arsénico del agua. Revista OPS ISSN 1020-4989

[10] Pierce, M.L. and Moore, C.B. 1982. Adsorption of Arsenite and arsenate on amorphous iron hydroxide. Water Res. 16, $1247-1253$.

[11] Pal, B.N. 2001. "Granular Ferric Hydroxide for Elimination of Arsenic from Drinking Water." In Technology for Arsenic Removal from Drinking Water, edited by M.F. Ahmed, M.A. Ali and Z. Adeel, 59-68. Dhaka: Ahmed, M. F.; Ali, M. A.; Adeel, Z.

[12] Storniolo, A.; Vidoni, R.; Pacini, V.; Ingallinella, A.; Sanguinetti, G.;2009 "Remocion de arsénico y otros elementos en aguas subterráneas". Reunion Presencia de fluor y arsénico en aguas subterráneas. La Pampa Argentina.

[13] Graieb, O.J.; Graieb V.C. y Tintilay S. C. 2006. Tecnología Para El abordaje del hacre en pobladores rurales dispersos CEDIA UTN-FRT.

[14] Ferrari R.R. y Graieb O.J. 2006. Selección de tecnologías para el tratamiento de aguas contaminadas con arsénico en países en desarrollo - CEDIA UTN-FRT.

[15] Falcón, C.M.; Graieb, O.J.; García, J.W. y Sayago, J.M. 2006. La Distribución del arsénico en los materiales loesicos en la llanura oriental tucumana, factores de su movilidad - CEDIA UTN-FRT.

[16] Graieb, O.J.; Iturre, A.E. y Moreno, P.G. 2006. Intervenciones Comunitarias Sustentables: estrategias metodológicas para el tratamiento del arsénico en el agua de consumo humano CEDIA UTN-FRT.

[17] Graieb, O.J. y Lujan, J.C. 2006. Química y Determinación Analítica del arsénico - CEDIA UTN-FRT. 